\title{
Living in Gang-Controlled Neighborhoods: Impacts on Electoral and Non-Electoral Participation in El Salvador
}

\author{
Abby Córdova \\ abby.cordova@uky.edu \\ Associate Professor, Political Science \\ University of Kentucky
}

ONLINE APPENDIX 


\section{Contents}

Table A1. Comparison of Neighborhood and Nationally Representative Samples (Population 18 years old or older)

Table A2. Description of Individual Level Variables Included in Table 1 in the Manuscript................... 2

Table A3. Description of Neighborhood Level Variables Included in Table 1 in the Manuscript ............. 4

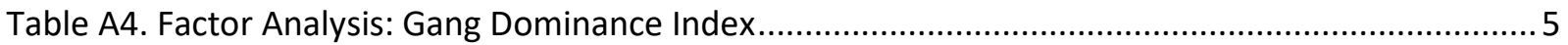

Table A5. Description of Variables Employed to Validate the Gang-Dominance Index. ....................... 6

Table A6. Dependent Variable: Reports of Graffiti (Index Validation) ................................................. 8

Table A7. Dependent Variable: Asked for Help to the Police (Index Validation) ................................... 9

Table A8. Dependent Variable: Fear of Crime (Index Validation) ....................................................... 10

Table A9. Dependent Variable: Talked to the Police (Index Validation) .............................................. 11

Table A10. Dependent Variable: Participation in Meeting of Neighborhood Organizations (Index

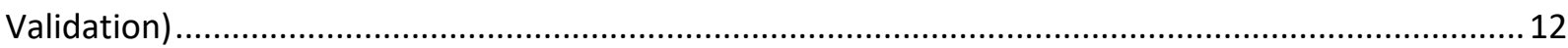

Figure A1. Gang Dominance Index Validation: Correlation with Physical Disorder ............................. 13

Figure A2. Gang Dominance Index Validation: Correlation with \% Households in Poverty ................... 14

Figure A3. Gang Index Validation: Correlation with Neighborhood Crime......................................... 15

Table A11. Dependent Variables: Protest Participation and Help Request from a Ministry.................. 16

Table A12. Average Treatment Effect (ATE) of Crime Victimization on Non-Electoral Participation ..... 17

Table A13. Dependent Variables: Crime Victimization and Frequency of Crime Victimization ............. 18

Table A14. Dependent Variable: Voting (Placebo test: Effect of Crime Victimization After Election) ... 19

Table A15. Dependent Variable: Interest in Politics ............................................................................ 20

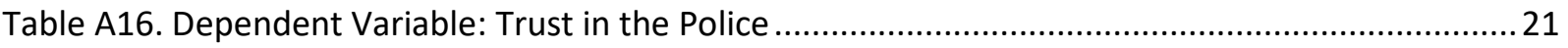

Table A17. Dependent Variable: Demand for Police Involvement in the Neighborhood .....................22

Table A18. Alternative Index of Gang Dominance: Signs of Graffiti in Census Track (based on the 2016 LAPOP national survey for El Salvador). 
Table A1. Comparison of Neighborhood and Nationally Representative Samples (Population 18 years old or older)

\begin{tabular}{|c|c|c|c|c|c|c|c|c|}
\hline \multirow[b]{3}{*}{ Women } & \multicolumn{4}{|c|}{$\begin{array}{c}\text { National Sample } \\
\text { (2010 AmericasBarometer) }\end{array}$} & \multicolumn{4}{|c|}{$\begin{array}{c}\text { Neighborhood Sample } \\
\text { (El Salvador) }\end{array}$} \\
\hline & \multirow{2}{*}{$\begin{array}{l}\text { Mean } \\
51.9 \%\end{array}$} & \multirow{2}{*}{$\begin{array}{c}\text { Std. } \\
\text { Err. } \\
1.3\end{array}$} & \multicolumn{2}{|c|}{$\begin{array}{l}\text { [95\% Conf. } \\
\text { Interval] }\end{array}$} & \multirow{2}{*}{$\begin{array}{l}\text { Mean } \\
49.4 \%\end{array}$} & \multirow{2}{*}{$\begin{array}{c}\text { Std. } \\
\text { Err. } \\
0.8\end{array}$} & \multicolumn{2}{|c|}{$\begin{array}{l}\text { [95\% Conf. } \\
\text { Interval] }\end{array}$} \\
\hline & & & $49.4 \%$ & $54.4 \%$ & & & $47.8 \%$ & $50.9 \%$ \\
\hline Age & 38.1 & 0.4 & 37.4 & 38.9 & 39.5 & 0.3 & 39.1 & 40.0 \\
\hline $\begin{array}{l}\text { No formal } \\
\text { education }\end{array}$ & $8.2 \%$ & 0.7 & $6.8 \%$ & $9.6 \%$ & $9.7 \%$ & 0.5 & $8.8 \%$ & $10.6 \%$ \\
\hline Primary education & $29.2 \%$ & 1.2 & $26.9 \%$ & $31.4 \%$ & $31.0 \%$ & 0.7 & $29.5 \%$ & $32.4 \%$ \\
\hline $\begin{array}{l}\text { Secondary } \\
\text { education }\end{array}$ & $42.3 \%$ & 1.3 & $39.9 \%$ & $44.8 \%$ & $45.3 \%$ & 0.8 & $43.8 \%$ & $46.9 \%$ \\
\hline Higher education & $20.3 \%$ & 1.0 & $18.3 \%$ & $22.3 \%$ & $14.0 \%$ & 0.5 & $12.9 \%$ & $15.1 \%$ \\
\hline Sample Size & \multicolumn{4}{|c|}{1,550} & \multicolumn{4}{|c|}{4,096} \\
\hline
\end{tabular}


Table A2. Description of Individual Level Variables Included in Table 1 in the Manuscript.

\begin{tabular}{|c|c|c|}
\hline $\begin{array}{l}\text { Individual-Level } \\
\text { Variable }\end{array}$ & Description & Instrument \\
\hline $\begin{array}{l}\text { Participation in } \\
\text { Meetings of a Political } \\
\text { Party }\end{array}$ & $\begin{array}{l}\text { Do you participate in meetings of a political party? } \\
\text { Never (4) Once or twice a year (3) Once or twice a } \\
\text { month (2) Once a week (1) }\end{array}$ & $\begin{array}{l}\text { Neighborhood } \\
\text { Public Opinion } \\
\text { Survey }\end{array}$ \\
\hline $\begin{array}{l}\text { Contacted Local } \\
\text { Government }\end{array}$ & $\begin{array}{l}\text { In order to solve your problems have you ever requested } \\
\text { help or cooperation from a local public official such as the } \\
\text { mayor or town council? } \\
\text { (1) Yes (0) No }\end{array}$ & $\begin{array}{l}\text { Neighborhood } \\
\text { Public Opinion } \\
\text { Survey }\end{array}$ \\
\hline Contacted a legislator & A member of the Legislative Assembly? (1) Yes (0) No & $\begin{array}{l}\text { Neighborhood } \\
\text { Public Opinion } \\
\text { Survey }\end{array}$ \\
\hline $\begin{array}{l}\text { Non-Electoral } \\
\text { Participation Index }\end{array}$ & $\begin{array}{l}\text { Count of five modes of participation: participation in } \\
\text { meetings of political parties, help requests from the local } \\
\text { government, a legislator or state ministry, and } \\
\text { participation in protests. The index ranges from } 0 \text { to } 5 \text {. }\end{array}$ & $\begin{array}{l}\text { Neighborhood } \\
\text { Public Opinion } \\
\text { Survey }\end{array}$ \\
\hline Crime victim & $\begin{array}{l}\text { Personal experience with at least one crime in the past } \\
\text { twelve months from a list of } 10 \text { types of crime. } \\
(=1 \text { if victimized; } 0=\mathrm{No} \text { ) }\end{array}$ & $\begin{array}{l}\text { Neighborhood } \\
\text { Public Opinion } \\
\text { Survey }\end{array}$ \\
\hline $\begin{array}{l}\text { Fear of being } \\
\text { victimized by crime in } \\
\text { the neighborhood }\end{array}$ & $\begin{array}{l}\text { Index based on the following two items: } \\
\text { How worried are you that someone will stop you in the } \\
\text { street, threaten you, hit you or hurt you in [NAME OF } \\
\text { NEIGHBORHOOD]? Are you...? } \\
\text { (4) Very worried (3) Somewhat worried (2) Not very } \\
\text { worried (1) Not worried } \\
\text { How worried are you that someone from your family will } \\
\text { be stopped in the street, threatened, hit or hurt in [NAME } \\
\text { OF NEIGHBORHOOD]? Are you...? } \\
\text { (4) Very worried (3) Somewhat worried (2) Not very } \\
\text { worried (1) Not worried } \\
\text { Unidimensional index with a Cronbach's alpha of } 0.88\end{array}$ & $\begin{array}{l}\text { Neighborhood } \\
\text { Public Opinion } \\
\text { Survey }\end{array}$ \\
\hline Trust toward neighbors & $\begin{array}{l}\text { Speaking of the people from around here, would you say } \\
\text { that people in [NAME OF NEIGHBORHOOD] are: } \\
\begin{array}{ll}\text { (4) Very trustworthy (3) Somewhat trustworthy } & \text { (2) Not } \\
\text { very trustworthy (1) Untrustworthy } & \end{array}\end{array}$ & $\begin{array}{l}\text { Neighborhood } \\
\text { Public Opinion } \\
\text { Survey }\end{array}$ \\
\hline
\end{tabular}




\begin{tabular}{l|l|l}
\hline Interest in Politics & $\begin{array}{l}\text { How much interest do you have in politics: a lot, some, } \\
\text { little or none? } \\
\begin{array}{l}\text { 4) A lot } \\
\text { None }\end{array}\end{array}$ & $\begin{array}{l}\text { Neighborhood } \\
\text { Public Opinion } \\
\text { Survey }\end{array}$ \\
\hline Quintiles of Wealth & $\begin{array}{l}\text { Variable estimated based on Principal Component } \\
\text { Analysis and 13 Household Assets (for details in the } \\
\text { methodology, see Córdova 2009) }\end{array}$ & $\begin{array}{l}\text { Neighborhood } \\
\text { Public Opinion } \\
\text { Survey }\end{array}$ \\
\hline Schooling & Years of schooling (ranges from 0 to 18) & $\begin{array}{l}\text { Neighborhood } \\
\text { Public Opinion } \\
\text { Survey }\end{array}$ \\
\hline Age & How old are you? & $\begin{array}{l}\text { Neighborhood } \\
\text { Public Opinion } \\
\text { Survey }\end{array}$ \\
\hline Sex & Female=1; Male=0 & $\begin{array}{l}\text { Neighborhood } \\
\text { Public Opinion } \\
\text { Survey }\end{array}$ \\
\hline
\end{tabular}


Table A3. Description of Neighborhood Level Variables Included in Table 1 in the Manuscript

\begin{tabular}{|c|c|c|}
\hline $\begin{array}{l}\text { Neighborhood-Level } \\
\text { Variable }\end{array}$ & Description & Instrument \\
\hline Gang Dominance Index & $\begin{array}{l}\text { Computed based on the following questions: } \\
\text { Please tell me which of the following situations is a } \\
\text { very serious problem, somewhat serious, not so } \\
\text { serious, not serious or not a problem in [NAME OF } \\
\text { NEIGHBORHOOD]. } \\
\text { Young people or children that live in [NAME OF } \\
\text { NEIGHBORHOOD] who are in gangs or maras } \\
\text { Gang or maras brawls or fights in [NAME OF } \\
\text { NEIBHBORHOOD] }\end{array}$ & $\begin{array}{l}\text { Neighborhood } \\
\text { Public Opinion } \\
\text { Survey }\end{array}$ \\
\hline $\begin{array}{l}\text { Absolute Living } \\
\text { Conditions in the } \\
\text { Neighborhood (Poverty) }\end{array}$ & $\begin{array}{l}\text { Based on the Unsatisfied Basic Needs Methodology as } \\
\text { described in Méndez and Trejos (2004) } \\
\text { \% Households living in poverty (with at least one basic } \\
\text { need unsatisfied) }\end{array}$ & $\begin{array}{l}\text { Census carried } \\
\text { out for the study }\end{array}$ \\
\hline Neighborhood Crime & $\begin{array}{l}\text { Index based on responses to seven items in the opinion } \\
\text { survey that asked respondents whether they had } \\
\text { knowledge of the following seven acts occurring in the } \\
\text { last twelve months in their neighborhood: robberies, } \\
\text { damage to private property, sale of illegal drugs, } \\
\text { extortions, sexual violence, kidnappings, and murders. } \\
\text { The index measures the average number of crimes } \\
\text { (from the list of seven possible crimes) that } \\
\text { respondents reported in each neighborhood and varies } \\
\text { between } 0 \text { and } 7\end{array}$ & $\begin{array}{l}\text { Neighborhood } \\
\text { Public Opinion } \\
\text { Survey }\end{array}$ \\
\hline Neighborhood Size & Number of inhabited households in the neighborhood & $\begin{array}{l}\text { Census carried } \\
\text { out for the study }\end{array}$ \\
\hline
\end{tabular}


Table A4. Factor Analysis: Gang Dominance Index

\begin{tabular}{|c|c|c|c|}
\hline & Question Wording & Factor I & Uniqueness \\
\hline 1. & Young people or children that live in [NAME OF & 0.9107 & 0.1706 \\
\hline & NEIGHBORHOOD] who are in gangs or maras? & & \\
\hline 2 . & Gang or maras brawls or fights in [NAME OF & 0.9107 & 0.1706 \\
\hline & NEIBHBORHOOD]? & & \\
\hline & \multicolumn{3}{|c|}{ Method: Principal-Component Factors; Rotation: Orthogonal Varimax } \\
\hline & \multicolumn{3}{|c|}{ Proportion of Variance Explained by Factor $\mathrm{I}=82.94 \%$} \\
\hline & \multicolumn{3}{|l|}{ Cronbach's alpha coefficient $=0.8$} \\
\hline
\end{tabular}


Table A5. Description of Variables Employed to Validate the Gang-Dominance Index.

\begin{tabular}{|c|c|c|}
\hline $\begin{array}{l}\text { Individual-Level } \\
\text { Variable }\end{array}$ & Description & Instrument \\
\hline Graffiti on the walls & $\begin{array}{l}\text { Please tell me which of the following } \\
\text { situations is a very serious problem, } \\
\text { somewhat serious, not so serious, not } \\
\text { serious or not a problem in [NAME OF } \\
\text { NEIGHBORHOOD]. } \\
\text { Tags or graffiti on the walls in [NAME OF } \\
\text { NEIBHBORHOOD] }\end{array}$ & $\begin{array}{l}\text { Neighborhood Public } \\
\text { Opinion Survey }\end{array}$ \\
\hline $\begin{array}{l}\text { Asking for help to the } \\
\text { police }\end{array}$ & $\begin{array}{l}\text { In order to protect yourself from a crime, in } \\
\text { the last } 12 \text { months, have you taken any } \\
\text { measure such as... Asking for help from the } \\
\text { police? (Yes }=1 ; 0=\text { No) }\end{array}$ & $\begin{array}{l}\text { Neighborhood Public } \\
\text { Opinion Survey }\end{array}$ \\
\hline Fear of crime & $\begin{array}{l}\text { Being at home with your family during the } \\
\text { day, would you feel...? Very Safe, } \\
\text { Somewhat Safe, Somewhat Unsafe, or Very } \\
\text { unsafe } \\
\text { Being home alone during the day, would } \\
\text { you feel...? } \\
\text { Being home alone at night, would you } \\
\text { feel...? } \\
\text { Walking alone in this neighborhood during } \\
\text { the day, would you feel...? } \\
\text { Walking alone in this neighborhood at } \\
\text { night, would you feel...? } \\
\text { Unidimensional index with a Cronbach's } \\
\text { alpha of } 0.81\end{array}$ & $\begin{array}{l}\text { Neighborhood Public } \\
\text { Opinion Survey }\end{array}$ \\
\hline $\begin{array}{l}\text { Saw neighbor talking to } \\
\text { the police }\end{array}$ & $\begin{array}{l}\text { In the last } 12 \text { months, which of the } \\
\text { following activities have you seen the } \\
\text { national civil police do in [NAME OF } \\
\text { NEIGHBORHOOD]? Talk with the } \\
\text { residents of [NAME OF } \\
\text { NEIGHBORHOOD] }(\mathrm{Yes}=1 ; \mathrm{No}=0)\end{array}$ & $\begin{array}{l}\text { Neighborhood Public } \\
\text { Opinion Survey }\end{array}$ \\
\hline $\begin{array}{l}\text { Participation in } \\
\text { meetings of } \\
\text { neighborhood } \\
\text { organizations }\end{array}$ & $\begin{array}{l}\text { Do you participate in meetings of a } \\
\text { committee for community improvement? } \\
\text { Never (4) Once or twice a year (3) Once or } \\
\text { twice a month (2) Once a week (1) }\end{array}$ & $\begin{array}{l}\text { Neighborhood Public } \\
\text { Opinion Survey }\end{array}$ \\
\hline Physical Disorder & $\begin{array}{l}\text { The physical disorder index consists of the } \\
\text { sum of five items from the block }\end{array}$ & $\begin{array}{l}\text { Systematic Observation of } \\
\text { Neighborhood Blocks }\end{array}$ \\
\hline
\end{tabular}




\begin{tabular}{|c|c|c|}
\hline & $\begin{array}{l}\text { observation: (1) garbage dumps or mounds } \\
\text { of trash scattered outdoors throughout the } \\
\text { area, (2) garbage or broken glass in the } \\
\text { streets or on sidewalks, (3) empty lots with } \\
\text { overgrown grass, (4) sewage or waste in the } \\
\text { streets, and (5) lack of public electricity. } \\
\text { The index was calculated at the } \\
\text { neighborhood level by averaging the scores } \\
\text { for blocks within each neighborhood. }\end{array}$ & \\
\hline $\begin{array}{l}\text { Absolute Living } \\
\text { Conditions in the } \\
\text { Neighborhood } \\
\text { (Poverty) }\end{array}$ & $\begin{array}{l}\text { Based on the Unsatisfied Basic Needs } \\
\text { Methodology as described in Méndez and } \\
\text { Trejos (2004). } \\
\text { The index measures the percentage of } \\
\text { households with at least one unsatisfied } \\
\text { basic need across four dimensions: } \\
\text { consumption capacity, education, health, } \\
\text { and housing. }\end{array}$ & $\begin{array}{l}\text { Census carried out for the } \\
\text { study }\end{array}$ \\
\hline Neighborhood Crime & $\begin{array}{l}\text { Index based on responses to seven items in } \\
\text { the opinion survey that asked respondents } \\
\text { whether they had knowledge of the } \\
\text { following seven acts occurring in the last } \\
\text { twelve months in their neighborhood: } \\
\text { robberies, damage to private property, sale } \\
\text { of illegal drugs, extortions, sexual violence, } \\
\text { kidnappings, and murders. The index } \\
\text { measures the average number of crimes } \\
\text { (from the list of seven possible crimes) that } \\
\text { respondents reported in each neighborhood } \\
\text { and varies between } 0 \text { and } 7\end{array}$ & $\begin{array}{l}\text { Neighborhood Public } \\
\text { Opinion Survey }\end{array}$ \\
\hline
\end{tabular}


Table A6. Dependent Variable: Reports of Graffiti (Index Validation)

\begin{tabular}{|c|c|}
\hline \\
\hline $\begin{array}{l}\text { Velghborhood-Level } \\
\text { Gang Dominance Index }\end{array}$ & $\begin{array}{c}0.052 * * * \\
(0.008)\end{array}$ \\
\hline Neighborhood Crime & $\begin{array}{c}0.024 \\
(0.043)\end{array}$ \\
\hline Poverty & $\begin{array}{l}-0.701^{*} \\
(0.288)\end{array}$ \\
\hline Neighborhood Size & $\begin{array}{l}-0.000 \\
(0.000)\end{array}$ \\
\hline Individual-Level & \\
\hline Crime Victim $(1=$ Yes; $0=$ No $)$ & $\begin{array}{l}-0.174 \\
(0.136)\end{array}$ \\
\hline Fear of Crime & $\begin{array}{l}1.621 * * * \\
(0.109)\end{array}$ \\
\hline Trust toward Neighbors & $\begin{array}{l}-0.060 \\
(0.040)\end{array}$ \\
\hline Years of Schooling & $\begin{array}{c}-0.023 * * \\
(0.008)\end{array}$ \\
\hline Quintiles of Wealth & $\begin{array}{l}0.041^{*} \\
(0.021)\end{array}$ \\
\hline $\operatorname{Sex}(1=$ Female $; 0=$ Male $)$ & $\begin{array}{l}-0.050 \\
(0.058)\end{array}$ \\
\hline Age & $\begin{array}{l}-0.006 \\
(0.009)\end{array}$ \\
\hline Age Squared & $\begin{array}{c}0.000 \\
(0.000)\end{array}$ \\
\hline Num. Neighborhoods & 71 \\
\hline Num. Obs. & 4,022 \\
\hline Model Specification & $\begin{array}{c}\text { Multilevel } \\
\text { Ordered Logit }\end{array}$ \\
\hline
\end{tabular}


Table A7. Dependent Variable: Asked for Help to the Police (Index Validation)

\begin{tabular}{|c|c|}
\hline \multicolumn{2}{|l|}{ Neighborhood-Level } \\
\hline Gang Dominance Index & $\begin{array}{c}-0.018 * \\
(0.009)\end{array}$ \\
\hline Neighborhood Crime & $\begin{array}{c}-0.002 \\
(0.051)\end{array}$ \\
\hline Poverty & $\begin{array}{c}0.875^{*} \\
(0.363)\end{array}$ \\
\hline Neighborhood Size & $\begin{array}{c}0.001 \\
(0.001)\end{array}$ \\
\hline Individual-Level & \\
\hline Crime Victim $(1=$ Yes; $0=$ No $)$ & $\begin{array}{c}0.526^{* *} \\
(0.198)\end{array}$ \\
\hline Fear of Crime & $\begin{array}{c}0.878 * * * \\
(0.205)\end{array}$ \\
\hline Trust toward Neighbors & $\begin{array}{l}-0.181 * \\
(0.072)\end{array}$ \\
\hline Interest in Politics & $\begin{array}{c}0.205 * * \\
(0.065)\end{array}$ \\
\hline Years of Schooling & $\begin{array}{l}-0.014 \\
(0.015)\end{array}$ \\
\hline Quintiles of Wealth & $\begin{array}{c}0.035 \\
(0.040)\end{array}$ \\
\hline $\operatorname{Sex}(1=$ Female $; 0=$ Male $)$ & $\begin{array}{c}0.081 \\
(0.112)\end{array}$ \\
\hline Age & $\begin{array}{c}0.042 * \\
(0.019)\end{array}$ \\
\hline Age Squared & $\begin{array}{c}-0.001 * \\
(0.000)\end{array}$ \\
\hline Constant & $\begin{array}{c}-3.065 * * * \\
(0.765)\end{array}$ \\
\hline Num. Neighborhoods & 71 \\
\hline Num. Obs. & 3,979 \\
\hline Model Specification & $\begin{array}{l}\text { Multilevel } \\
\text { Logit }\end{array}$ \\
\hline
\end{tabular}

$+p<0.10 ;{ }^{*} p<0.05 ; * * p<0.01 ; * * * p<0.001$ (Standard errors in parenthesis). Fixed effects at the municipal level included but not shown. 
Table A8. Dependent Variable: Fear of Crime (Index Validation)

\begin{tabular}{l|c}
\hline Neighborhood-Level & \\
Gang Dominance Index & $0.002^{* * *}$ \\
& $(0.001)$ \\
Poverty & 0.026 \\
& $(0.024)$ \\
Neighborhood Size & -0.000 \\
& $(0.000)$ \\
Individual-Level & \\
Crime Victim $(1=$ Yes; $0=$ No) & $0.050^{* * *}$ \\
& $(0.014)$ \\
Fear of Crime & $-0.067 * *$ \\
& $(0.004)$ \\
Trust toward Neighbors & 0.000 \\
& $(0.001)$ \\
Years of Schooling & $-0.009 * * *$ \\
& $(0.002)$ \\
Quintiles of Wealth & $0.028^{* * *}$ \\
& $(0.006)$ \\
Sex $(1=$ Female; $0=$ Male) & 0.002 \\
Age & $(0.001)$ \\
Age Squared & -0.000 \\
Constant & $(0.000)$ \\
Num. Neighborhoods & $0.050^{* * *}$ \\
Num. Obs. & $(0.014)$ \\
Model Specification & $0.383^{* * *}$ \\
parenthesis). Fixed effects at the municipal level included but not \\
Lhown. & $(0.051)$ \\
71 \\
\\
\end{tabular}


Table A9. Dependent Variable: Talked to the Police (Index Validation)

\begin{tabular}{|c|c|}
\hline \\
\hline $\begin{array}{l}\text { Neighborhood-Level } \\
\text { Gang Dominance Index }\end{array}$ & $\begin{array}{l}-0.018^{*} \\
(0.009)\end{array}$ \\
\hline Neighborhood Crime & $\begin{array}{c}0.050 \\
(0.050)\end{array}$ \\
\hline Poverty & $\begin{array}{c}1.575^{* * *} * \\
(0.344)\end{array}$ \\
\hline Neighborhood Size & $\begin{array}{l}0.001+ \\
(0.001)\end{array}$ \\
\hline \multicolumn{2}{|l|}{ Individual-Level } \\
\hline Crime Victim $(1=$ Yes; $0=$ No $)$ & $\begin{array}{l}-0.118 \\
(0.170)\end{array}$ \\
\hline Fear of Crime & $\begin{array}{l}-0.114 \\
(0.134)\end{array}$ \\
\hline Trust toward Neighbors & $\begin{array}{l}-0.081 \\
(0.050)\end{array}$ \\
\hline Years of Schooling & $\begin{array}{c}0.032 * * \\
(0.011)\end{array}$ \\
\hline Quintiles of Wealth & $\begin{array}{c}0.000 \\
(0.028)\end{array}$ \\
\hline $\operatorname{Sex}(1=$ Female; $0=$ Male $)$ & $\begin{array}{l}0.138+ \\
(0.078)\end{array}$ \\
\hline Age & $\begin{array}{c}0.003 \\
(0.013)\end{array}$ \\
\hline Age Squared & $\begin{array}{c}0.000 \\
(0.000)\end{array}$ \\
\hline Constant & $\begin{array}{l}-1.580^{*} \\
(0.648)\end{array}$ \\
\hline Num. Neighborhoods & 71 \\
\hline Num. Obs. & 3,999 \\
\hline Model Specification & $\begin{array}{c}\text { Multilevel } \\
\text { Logit Model }\end{array}$ \\
\hline
\end{tabular}


Table A10. Dependent Variable: Participation in Meeting of Neighborhood Organizations (Index Validation)

\begin{tabular}{|c|c|}
\hline \multicolumn{2}{|l|}{ Neighborhood-Level } \\
\hline Gang Dominance Index & $\begin{array}{c}-0.047 * * \\
(0.016)\end{array}$ \\
\hline Neighborhood Crime & $\begin{array}{l}0.155+ \\
(0.094)\end{array}$ \\
\hline Poverty & $\begin{array}{l}1.525^{*} \\
(0.653)\end{array}$ \\
\hline Neighborhood Size & $\begin{array}{l}-0.001 \\
(0.001)\end{array}$ \\
\hline Individual-Level & \\
\hline Crime Victim $(1=$ Yes; $0=$ No $)$ & $\begin{array}{l}0.454^{*} \\
(0.199)\end{array}$ \\
\hline Fear of Crime & $\begin{array}{c}0.074 \\
(0.185)\end{array}$ \\
\hline Trust toward Neighbors & $\begin{array}{l}0.126+ \\
(0.071)\end{array}$ \\
\hline Interest in Politics & $\begin{array}{c}0.044 \\
(0.068)\end{array}$ \\
\hline Years of Schooling & $\begin{array}{c}0.024 \\
(0.015)\end{array}$ \\
\hline Quintiles of Wealth & $\begin{array}{c}0.056 \\
(0.040)\end{array}$ \\
\hline Sex $(1=$ Female; $0=$ Male $)$ & $\begin{array}{l}-0.128 \\
(0.112)\end{array}$ \\
\hline Age & $\begin{array}{c}0.115^{* * * *} \\
(0.021)\end{array}$ \\
\hline Age Squared & $\begin{array}{c}-0.001 * * * \\
(0.000)\end{array}$ \\
\hline Num. Neighborhoods & 71 \\
\hline Num. Obs. & 3,974 \\
\hline Model Specification & $\begin{array}{l}\text { Multilevel } \\
\text { Ordered Logit }\end{array}$ \\
\hline
\end{tabular}


Figure A1. Gang Dominance Index Validation: Correlation with Physical Disorder

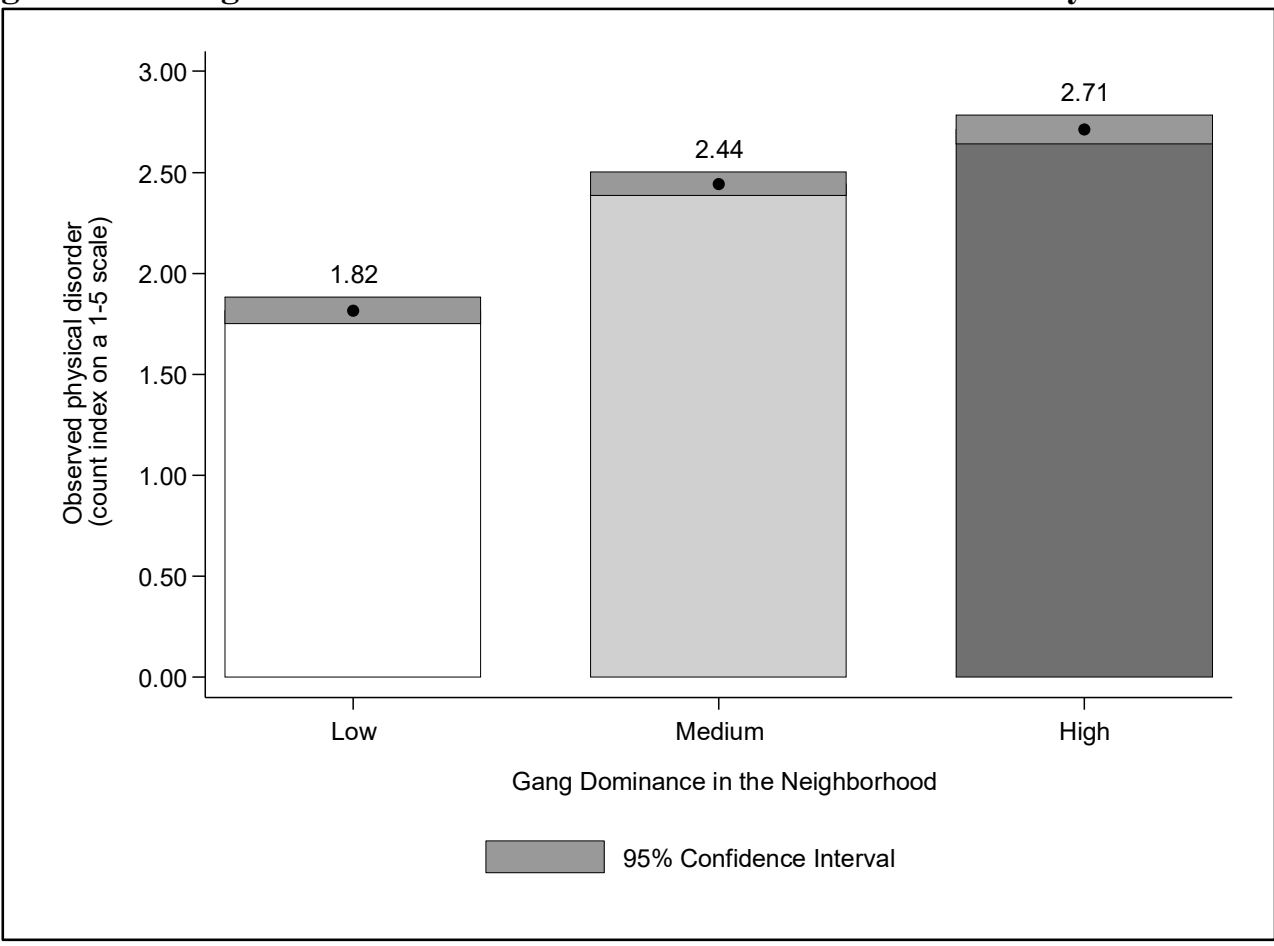

*With the purpose of displaying descriptive statistics graphically, the gang dominance index was divided into terciles to classify neighborhoods as having low, medium, or high levels of gang dominance. Following previous work in sociology (e.g., Sampson and Raudenbush 1999), a systematic observation of the physical deterioration of public spaces was conducted by fieldwork personnel in each neighborhood block prior to the collection of census and survey data. Based on these data, I computed a physical disorder index using the following items in the systematic observation questionnaire: (1) garbage dumps or mounds of trash scattered outdoors; (2) garbage or broken glass in the streets or on sidewalks; (3) empty lots with overgrown grass; (4) sewage or waste in the streets; and (5) lack of public electricity. 
Figure A2. Gang Dominance Index Validation: Correlation with \% Households in Poverty

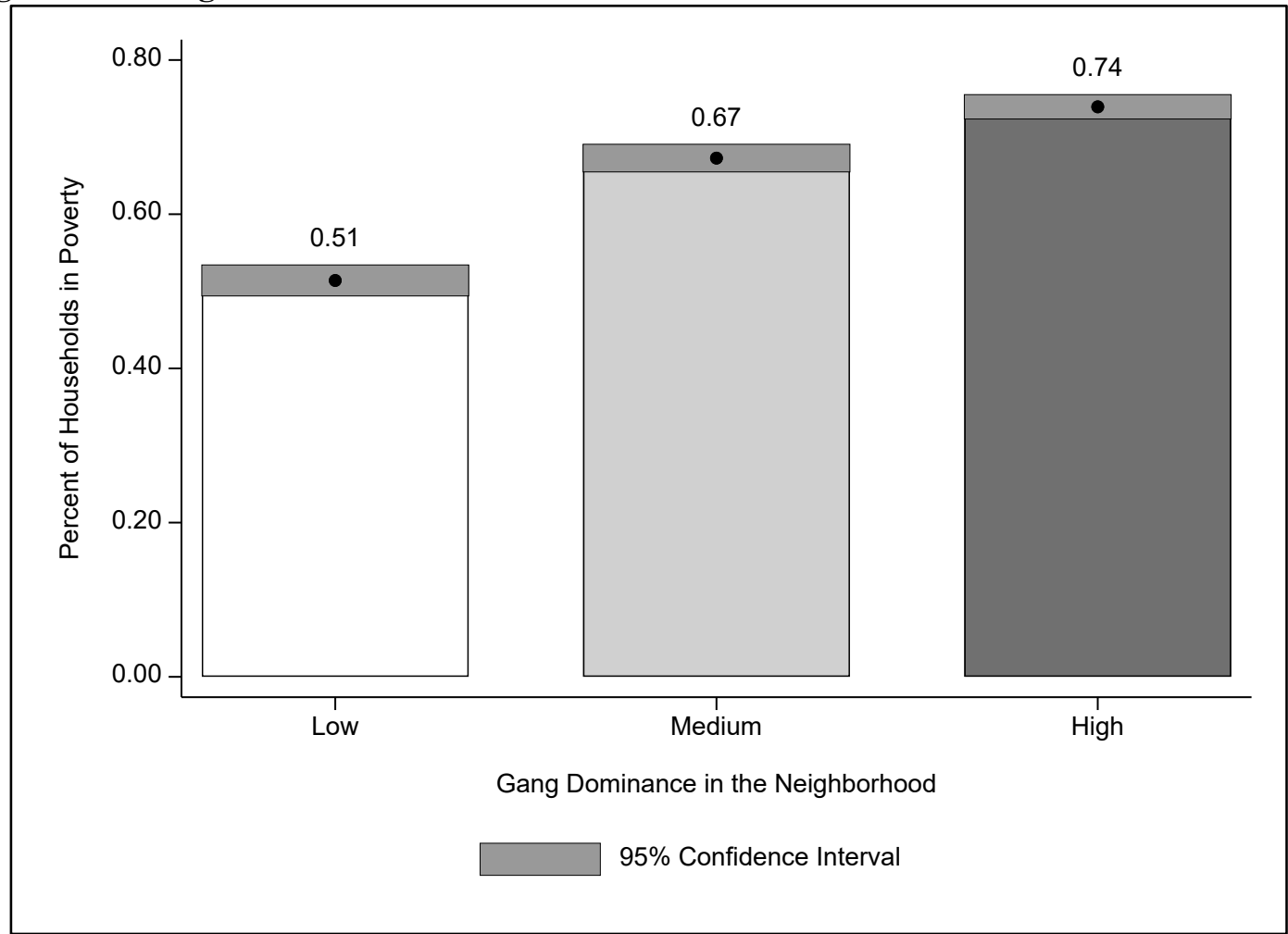

*Poverty is measured based on the Unsatisfied Basic Needs (UBN) methodology using data from the neighborhood census. The index measures the percentage of households with at least one unsatisfied basic need across four dimensions: consumption capacity, education, health, and housing 
Figure A3. Gang Index Validation: Correlation with Neighborhood Crime

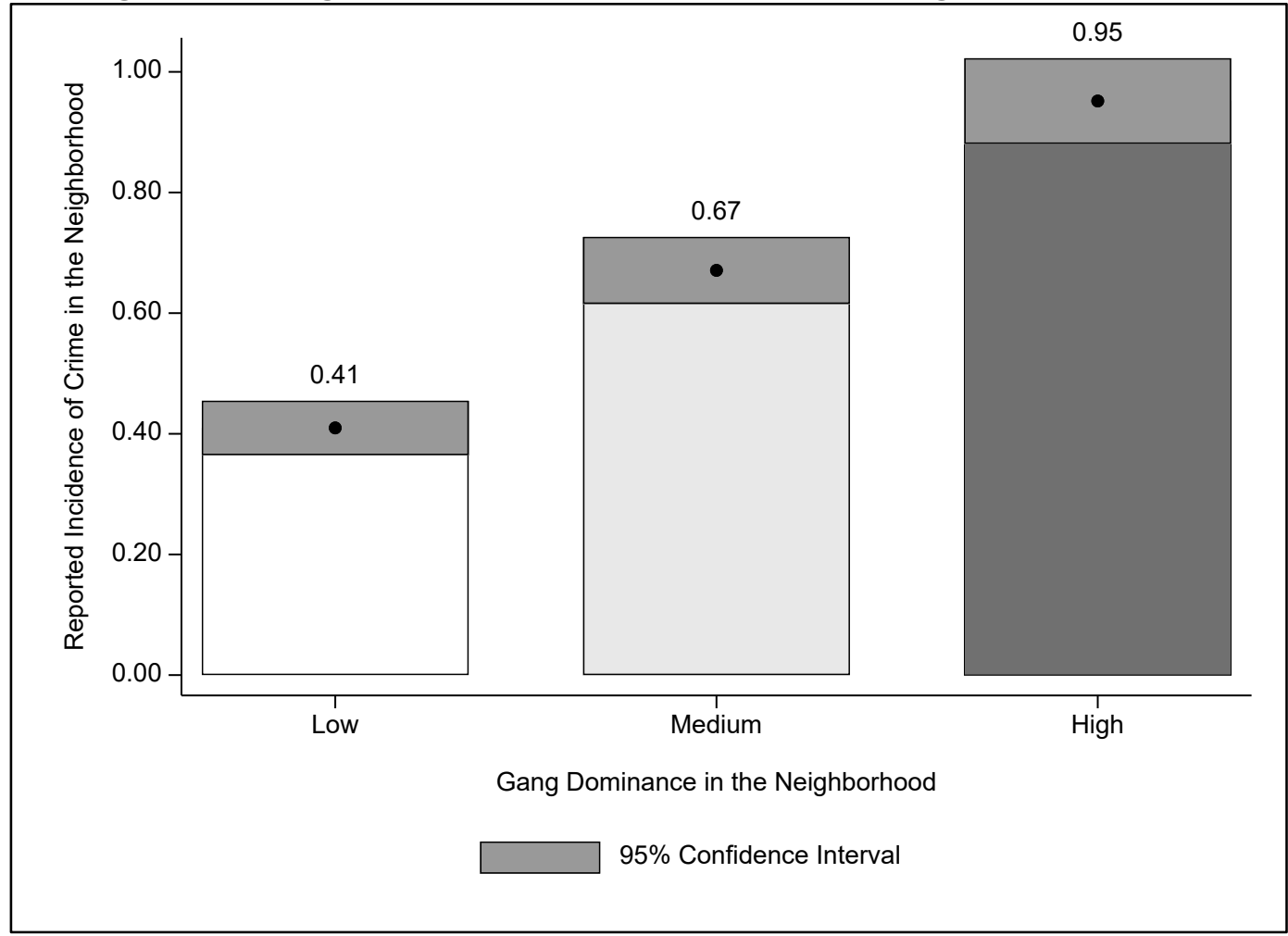

*Neighborhood crime is measured based on responses to seven items in the opinion survey that asked respondents whether they had knowledge of the following seven acts occurring in the last twelve months in their neighborhood: robberies, damage to private property, sale of illegal drugs, extortions, sexual violence, kidnappings, and murders. 
Table A11. Dependent Variables: Protest Participation and Help Request from a Ministry

Neighborhood-Level

Gang Dominance Index

Neighborhood Crime

Poverty

Neighborhood Size

Individual-Level

Crime Victim ( $1=$ Yes; $0=$ No)

Fear of Crime

Trust toward Neighbors

Interest in Politics

Years of Schooling

Quintiles of Wealth

Sex $(1=$ Female; $0=$ Male $)$

Age

Age Squared

Num. Neighborhoods

Num. Obs.

Model Specification
Protest Participation

$-0.039+$

$(0.023)$

0.053

$(0.128)$

0.488

(0.868)

0.001

(0.001)

$0.845^{*}$

(0.343)

$-0.088$

(0.363)

$-0.242+$

(0.136)

$0.472 * * *$

(0.109)

0.039

(0.028)

0.031

(0.075)

$-0.100$

(0.214)

$0.064+$

(0.039)

$-0.001$

(0.000)

71

3,997

Multilevel

Logit
Requested Help from State Ministry

$-0.040 * *$

$(0.015)$

0.085

$(0.089)$

1.007

(0.671)

0.000

(0.001)

$0.659^{*}$

(0.313)

$-0.152$

(0.311)

$0.210+$

(0.121)

$0.294 * *$

(0.099)

0.038

(0.024)

0.065

$(0.065)$

0.112

(0.181)

$0.057+$

(0.032)

$-0.001+$

(0.000)

71

3,979

Multilevel

Logit

$+p<0.10 ; * p<0.05 ; * * p<0.01 ; * * * p<0.001$ (Standard errors in parenthesis). Fixed effects at the municipal level included but not shown. 
Table A12. Average Treatment Effect (ATE) of Crime Victimization on Non-Electoral Participation

\begin{tabular}{lc}
\hline Dependent Variable & ATE (Coeff.) \\
Participated Political Party Activities & $.0525^{* *}$ \\
Contacted Local Government & $.0879 * *$ \\
Contacted Legislator & $.0973^{* * *}$ \\
Non-Electoral Participation Index & $.305^{* * *}$ \\
$* * p<0.01 ; * * * p<0.001$ & \\
\hline Results are based on the augmented inverse propensity weighted estimator. The outcome model \\
includes all control variables included in the regression models displayed in Table 1. The \\
propensity score model predicts the probability of treatment as a function of participation in \\
neighborhood improvement committees and respondents' demographic characteristics, including \\
household wealth, education level, sex, and age.
\end{tabular}


Table A13. Dependent Variables: Crime Victimization and Frequency of Crime Victimization

\begin{tabular}{l|c|c}
\hline & Crime Victimization & $\begin{array}{c}\text { Frequency of Crime } \\
\text { Victimization }\end{array}$ \\
\hline Neighborhood-Level & 0.012 & $0.002^{*}$ \\
Gang Dominance Index & $(0.009)$ & $(0.001)$ \\
Poverty & $1.650^{* * *}$ & $0.255^{* * *}$ \\
Neighborhood Size & $(0.425)$ & $(0.048)$ \\
& 0.001 & 0.000 \\
Individual-Level & $(0.001)$ & $(0.000)$ \\
Years of Schooling & 0.015 & $0.006^{*}$ \\
Quintiles of Wealth & $(0.019)$ & $(0.002)$ \\
Sex (1=Female; $0=$ Male) & 0.075 & 0.003 \\
Age & $(0.051)$ & $(0.006)$ \\
& -0.082 & 0.012 \\
Age Squared & $(0.143)$ & $(0.018)$ \\
Num. Neighborhoods & 0.022 & -0.003 \\
Num. Obs. & $(0.024)$ & $(0.003)$ \\
Model Specification & -0.000 & 0.000 \\
& $(0.000)$ & $(0.000)$ \\
& 71 & 71 \\
\hline & 4,089 & 4,085 \\
& Multilevel & Multilevel \\
\end{tabular}

$+p<0.10 ; * p<0.05 ; * * p<0.01 ; * * * p<0.001$ (Standard errors in parenthesis). Fixed effects at the municipal level included but not shown. The frequency of crime victimization variable measures the number of times individuals reported being victims of crime in the past twelve months. 
Table A14. Dependent Variable: Voting (Placebo test: Effect of Crime Victimization After Election)

\begin{tabular}{|c|c|}
\hline \multirow{2}{*}{$\begin{array}{l}\text { Neighborhood-Level } \\
\text { Gang Dominance Index }\end{array}$} & \\
\hline & $\begin{array}{l}-0.004 \\
(0.006)\end{array}$ \\
\hline Neighborhood Crime & $\begin{array}{c}0.023 \\
(0.032)\end{array}$ \\
\hline Poverty & $\begin{array}{c}0.336 \\
(0.209)\end{array}$ \\
\hline Neighborhood Size & $\begin{array}{l}0.001 * \\
(0.000)\end{array}$ \\
\hline Individual-Level & \\
\hline Crime Victim $(1=$ Yes; $0=$ No $)$ & $\begin{array}{l}-0.104 \\
(0.166)\end{array}$ \\
\hline Fear of Crime & $\begin{array}{c}0.023 \\
(0.130)\end{array}$ \\
\hline Trust toward Neighbors & $\begin{array}{l}-0.066 \\
(0.049)\end{array}$ \\
\hline Interest in Politics & $\begin{array}{c}0.240 * * * \\
(0.049)\end{array}$ \\
\hline Years of Schooling & $\begin{array}{c}0.044 * * * \\
(0.010)\end{array}$ \\
\hline Quintiles of Wealth & $\begin{array}{c}0.085 * * \\
(0.027)\end{array}$ \\
\hline Sex $(1=$ Female; $0=$ Male $)$ & $\begin{array}{l}-0.054 \\
(0.075)\end{array}$ \\
\hline Age & $\begin{array}{c}0.177 * * * \\
(0.012)\end{array}$ \\
\hline Age Squared & $\begin{array}{c}-0.002 * * * \\
(0.000)\end{array}$ \\
\hline Num. Neighborhoods & 71 \\
\hline Num. Obs. & 3,998 \\
\hline Model Specification & $\begin{array}{c}\text { Multileve } \\
\text { Logit }\end{array}$ \\
\hline
\end{tabular}


Table A15. Dependent Variable: Interest in Politics

\begin{tabular}{|c|c|}
\hline & Interest in Politics \\
\hline \multicolumn{2}{|l|}{ Neighborhood-Level } \\
\hline Gang Dominance Index & $\begin{array}{l}-0.009 \\
(0.006)\end{array}$ \\
\hline Neighborhood Crime & $\begin{array}{l}-0.005 \\
(0.032)\end{array}$ \\
\hline Poverty & $\begin{array}{c}0.392 \\
(0.219)\end{array}$ \\
\hline Neighborhood Size & $\begin{array}{c}0.000 \\
(0.000)\end{array}$ \\
\hline Individual-Level & \\
\hline Crime Victim $(1=$ Yes; $0=$ No $)$ & $\begin{array}{c}0.014 \\
(0.139)\end{array}$ \\
\hline Fear of Crime & $\begin{array}{l}-0.061 \\
(0.111)\end{array}$ \\
\hline Trust toward Neighbors & $\begin{array}{l}0.134 * * \\
(0.042)\end{array}$ \\
\hline Years of Schooling & $\begin{array}{c}0.013 \\
(0.009)\end{array}$ \\
\hline Quintiles of Wealth & $\begin{array}{c}0.118^{* * * *} \\
(0.023)\end{array}$ \\
\hline Sex $(1=$ Female; $0=$ Male $)$ & $\begin{array}{c}-0.488^{* * * *} \\
(0.063)\end{array}$ \\
\hline Age & $\begin{array}{c}0.011 \\
(0.010)\end{array}$ \\
\hline Age Squared & $\begin{array}{l}-0.000 \\
(0.000)\end{array}$ \\
\hline _cons & $\begin{array}{c}0.027 \\
(0.016)\end{array}$ \\
\hline Num. Neighborhoods & 71 \\
\hline Num. Obs. & 4,012 \\
\hline Model Specification & $\begin{array}{l}\text { Multilevel } \\
\text { Ordered Logit }\end{array}$ \\
\hline
\end{tabular}

$+p<0.10 ; * p<0.05 ; * * p<0.01 ; * * * p<0.001$ (Standard errors in parenthesis). Fixed effects at the municipal level included but not shown. 
Table A16. Dependent Variable: Trust in the Police

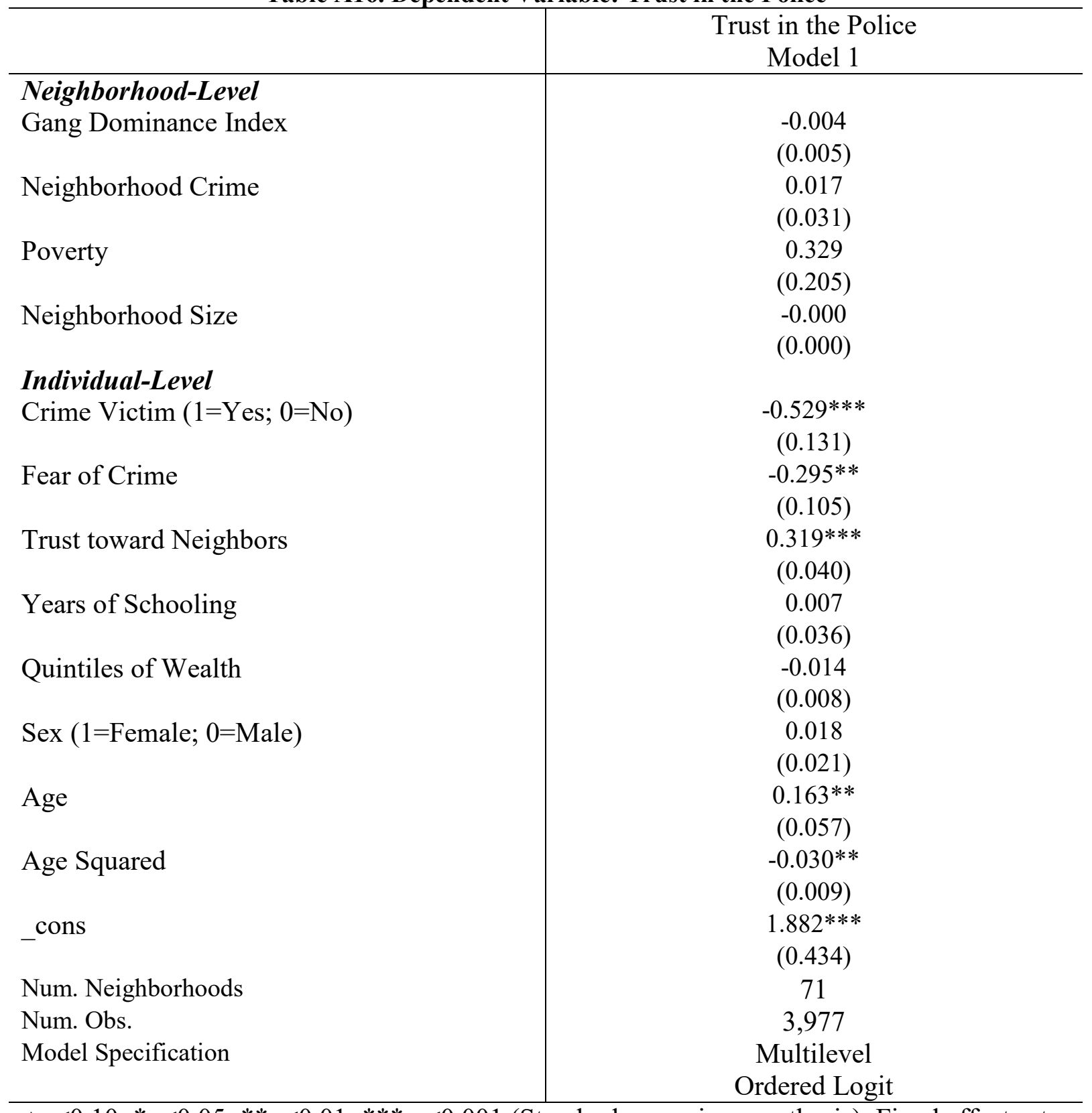

$+p<0.10 ; * p<0.05 ; * * p<0.01 ; * * * p<0.001$ (Standard errors in parenthesis). Fixed effects at the municipal level included but not shown. 
Table A17. Dependent Variable: Demand for Police Involvement in the Neighborhood

\begin{tabular}{|c|c|}
\hline & Demand for Police Involvement \\
\hline \multicolumn{2}{|l|}{ Neighborhood-Level } \\
\hline \multirow[t]{2}{*}{ Gang Dominance Index } & -0.011 \\
\hline & $(0.017)$ \\
\hline \multirow[t]{2}{*}{ Neighborhood Crime } & 0.051 \\
\hline & $(0.096)$ \\
\hline \multirow[t]{2}{*}{ Poverty } & $-1.953 * *$ \\
\hline & $(0.687)$ \\
\hline \multirow[t]{2}{*}{ Neighborhood Size } & $-0.003 * *$ \\
\hline & $(0.001)$ \\
\hline \multicolumn{2}{|l|}{ Individual-Level } \\
\hline \multirow[t]{2}{*}{ Crime Victim $(1=\mathrm{Yes} ; 0=\mathrm{No})$} & -0.462 \\
\hline & $(0.251)$ \\
\hline \multirow[t]{2}{*}{ Fear of Crime } & 0.174 \\
\hline & $(0.242)$ \\
\hline \multirow[t]{2}{*}{ Trust toward Neighbors } & 0.117 \\
\hline & $(0.088)$ \\
\hline \multirow[t]{2}{*}{ Years of Schooling } & -0.139 \\
\hline & $(0.083)$ \\
\hline \multirow[t]{2}{*}{ Quintiles of Wealth } & 0.006 \\
\hline & $(0.019)$ \\
\hline \multirow[t]{2}{*}{ Sex $(1=$ Female; $0=$ Male $)$} & -0.074 \\
\hline & $(0.050)$ \\
\hline \multirow[t]{2}{*}{ Age } & -0.047 \\
\hline & $(0.141)$ \\
\hline \multirow[t]{2}{*}{ Age Squared } & 0.027 \\
\hline & $(0.022)$ \\
\hline \multirow[t]{2}{*}{ _cons } & $1.882 * * *$ \\
\hline & $(0.434)$ \\
\hline Num. Neighborhoods & 71 \\
\hline Num. Obs. & 4,001 \\
\hline Model Specification & Multilevel \\
\hline & Ordered Logit \\
\hline
\end{tabular}

$+p<0.10 ; * p<0.05 ; * * p<0.01 ; * * * p<0.001$ (Standard errors in parenthesis). Fixed effects at the municipal level included but not shown. 
Table A18. Alternative Index of Gang Dominance: Signs of Graffiti in Census Track (based on the 2016 LAPOP national survey for EI Salvador)

\begin{tabular}{l|c|c}
\hline & $\begin{array}{c}\text { Participation in Meeting of } \\
\text { Political Parties }\end{array}$ & $\begin{array}{c}\text { Voting in Past } \\
\text { Presidential Election }\end{array}$ \\
\hline Census Track-Level & $-0.824^{* *}$ & -0.265 \\
Gang Dominance Index & $(0.309)$ & $(0.241)$ \\
Crime Level & 0.309 & 0.479 \\
Individual-Level & $(0.381)$ & $(0.315)$ \\
Crime Victim (1=Yes; 0=No) & 0.094 & \\
Fear of Crime & $(0.189)$ & \\
& -0.089 & -0.116 \\
Interest in Politics & $(0.080)$ & $(0.068)$ \\
& $0.566^{* * *}$ & $0.389 * * *$ \\
Years of Schooling & $(0.073)$ & $(0.070)$ \\
Quintiles of Wealth & -0.074 & $0.473 * * *$ \\
& $(0.118)$ & $(0.106)$ \\
Sex (1=Female; 0=Male) & -0.024 & -0.045 \\
& $(0.057)$ & $(0.048)$ \\
Age & -0.132 & 0.056 \\
& $(0.158)$ & $(0.132)$ \\
cons & -0.003 & $0.071 * * *$ \\
Num. Census Tracts & $(0.005)$ & $(0.006)$ \\
Num. Obs. & 0.216 & $-3.507^{* * *}$ \\
Model Specification & $(0.168)$ & $(0.698)$ \\
& 252 & 252 \\
+ & 1,499 & 1,501 \\
& Multilevel & Multilevel \\
& Ordered Logit & Logit \\
\hline
\end{tabular}

$+p<0.10 ; * p<0.05 ; * * p<0.01 ; * * * p<0.001$ (Standard errors in parenthesis). 